Article

\title{
The Effect of Acute Erythromycin Exposure on the Swimming Ability of Zebrafish (Danio rerio) and Medaka (Oryzias latipes)
}

\author{
Yanyi Li and Jiabo Zhang * \\ College of Fisheries, Huazhong Agricultural University, Wuhan 430000, China; lyy773981695@163.com \\ * Correspondence: zjb@mail.hzau.edu.cn
}

Received: 7 February 2020; Accepted: 17 April 2020; Published: 13 May 2020

\begin{abstract}
Erythromycin is a widely used antibiotic, and erythromycin contamination may pose a threat to aquatic organisms. However, little is known about the adverse effects of erythromycin on swimming ability. To quantify erythromycin-induced damage to fish swimming ability, Oryzias latipes and Danio rerio were acutely exposed to erythromycin. The swimming ability of the experimental fish was measured after exposure to varying doses of erythromycin $(2 \mu \mathrm{g} / \mathrm{L}, 20 \mu \mathrm{g} / \mathrm{L}, 200 \mu \mathrm{g} / \mathrm{L}$, and $2 \mathrm{mg} / \mathrm{L}$ ) for $96 \mathrm{~h}$. Burst speed ( $\left.\mathrm{U}_{\text {burst }}\right)$ and critical swimming speed $\left(\mathrm{U}_{\text {crit }}\right)$ of experimental fish significantly decreased. In addition, gene expression analysis of $O$. latipes and $D$. rerio under erythromycin treatment $(2 \mathrm{mg} / \mathrm{L})$ showed that the expression of genes related to energy metabolism in the muscle was significantly reduced in both species of fish. However, the gene expression pattern in the head of the two species was differentially impacted; $D$. rerio showed endocrine disruption, while phototransduction was impacted in O. latipes. The results of our study may be used as a reference to control erythromycin pollution in natural rivers.
\end{abstract}

Keywords: erythromycin; swimming ability; mRNA; Oryzias latipes; Danio rerio

\section{Introduction}

Antibiotics are frequently used worldwide for sterilization and to maintain health [1,2]. It has been reported that $80 \%$ of antibiotics enter the aquatic environment in their original form $[3,4]$. Moreover, studies have shown that antibiotics are widely detected in aquatic systems [5]. Antibiotics are considered to be a pollutant with a sustained adverse effect on the ecological environment [6]. Adverse effects on fish have been widely reported; for example, antibiotics have been shown to delay the hatching of fish eggs [7], damage gills and liver [8], and destroy the antioxidant defenses in muscle, which affects fish metabolism [1,9] and injures neurons [1,9]. Antibiotics are usually detected in rivers and wastewater at the level of ug/L [3]. However, previous studies have found concentrations of antibiotics at $\mathrm{mg} / \mathrm{L}$ levels in swine wastewater [10-12], and erythromycin is commonly used for livestock farming [13].

Erythromycin, a semisynthetic antibiotic bacteriostatic, has been a widely used antibiotic since the 1950s [14]. Sewage treatment systems do not efficiently dispose of organic pollutants; thus, erythromycin is ubiquitous in the aquatic environment [15]. It takes a long time for erythromycin to degrade naturally [16]; in addition, previous studies have demonstrated that erythromycin has adverse effects on fish [16-18]. However, these studies focused on the physiological impacts on fish, rather than the negative effects on behavior [19].

The swimming behavior of fish is closely related to all the life activities of fish. Burst speed $\left(\mathrm{U}_{\text {burst }}\right)$ and critical swimming speed $\left(\mathrm{U}_{\text {crit }}\right)$ are important aspects of swimming ability because they play significant roles in the life activities of fish. $\mathrm{U}_{\text {burst }}$ is vitally important for activities such as 
eating, avoiding predators, and competitive interaction [20,21], while $\mathrm{U}_{\text {crit }}$ may be critical for seasonal behaviors associated with migration and reproduction. In addition, $\mathrm{U}_{\text {crit }}$ and $\mathrm{U}_{\text {burst }}$ represent the aerobic and anaerobic capacity of fish, respectively. Red muscle contains hemoglobin, myoglobin, and mitochondria, and is connected to the vascular system. This muscle is thought to have a metabolic function associated with aerobic exercise. White muscle provides a strong but limited burst of movement [22]. The movement of fish depends directly on the energy expenditure of muscles. In addition, the nervous system in the brain is stimulated by environmental pollutants, which can also lead to abnormal behavioral patterns and swimming activity [23]. Swimming patterns may be affected by gene expression, which is obviously regulated by the stress response of fish to erythromycin.

In this experiment, Oryzias latipes and Danio rerio were exposed to different concentrations of erythromycin $(2 \mu \mathrm{g} / \mathrm{L}, 20 \mu \mathrm{g} / \mathrm{L}, 200 \mu \mathrm{g} / \mathrm{L}$, and $2 \mathrm{mg} / \mathrm{L})$ for $96 \mathrm{~h}$, and the $U_{\text {crit }}$ and $U_{\text {burst }}$ of each treatment group were compared. Based on the swimming ability results, the gene expressions of O. latipes and $D$. rerio treated with erythromycin $(2 \mathrm{mg} / \mathrm{L})$ were analyzed. According to the results of gene expression, the expression of selected genes in each treatment group was verified by qRT-PCR. This study provides a factual basis for studying the effects of erythromycin on fish gene expression and swimming ability.

\section{Materials and Methods}

\subsection{Experimental Fish}

D. rerio and O. latipes are classic model species. Four-month-old D. rerio and 6-month-old Singaporean O. latipes were obtained from Shanghai Feixi Biotechnology Co., Ltd. (Shanghai, China). The average weight $( \pm \mathrm{SD})$ and average length $( \pm \mathrm{SD})$ of the $D$. rerio used in this study were $0.56 \pm 0.08 \mathrm{~g}$ and $2.83 \pm 0.10 \mathrm{~cm}$, respectively. O. latipes had an average weight of $0.28 \pm 0.03 \mathrm{~g}$ and an average fork length of $3.23 \pm 0.05 \mathrm{~cm}$. After the experimental fish were transported to the laboratory, they were put into a plexiglass tank (Figure 1) $(25 \mathrm{~cm}$ long, $25 \mathrm{~cm}$ wide, $35 \mathrm{~cm}$ deep) filled with tap water aerated in advance. In addition, these fish were temporarily kept in the tank to eliminate the stress of the transport process. During this period, the fish were kept under a $14 \mathrm{~L} / 10 \mathrm{D}$ photoperiod, and they were hand-fed a commercial diet (Chengdu, China) containing $>40 \%$ protein and $>7 \%$ lipids. Moreover, the water temperature, dissolved oxygen and $\mathrm{pH}$ were maintained at $26.5 \pm 2{ }^{\circ} \mathrm{C}, 99.2 \pm 0.3 \%$ and $7.7 \pm 0.2$, respectively. Approximately one-third of the water in the tank was replaced twice per day with pre-aerated tap water.

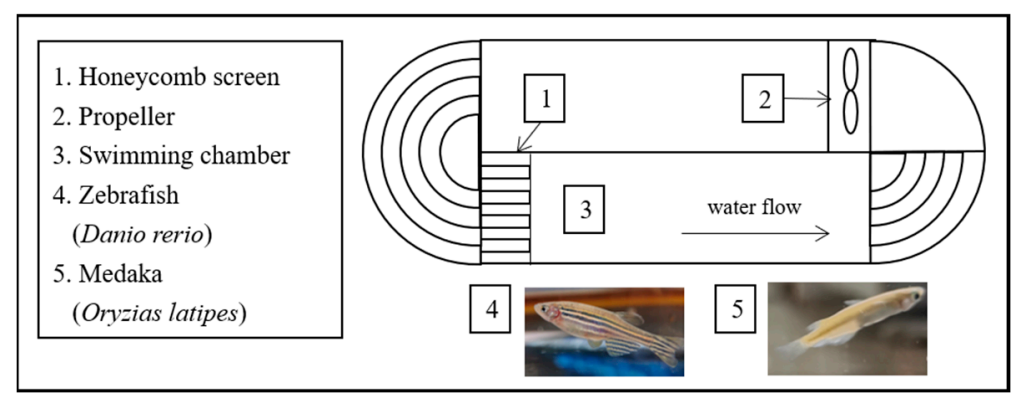

Figure 1. Sketch of the experimental setup in the laboratory.

\subsection{Experimental Design}

D. rerio and O. latipes were exposed to different concentrations of erythromycin (Sigma Aldrich, CAS: 114-07-8) at $0 \mu \mathrm{g} / \mathrm{L}, 2 \mu \mathrm{g} / \mathrm{L}, 20 \mu \mathrm{g} / \mathrm{L}, 200 \mu \mathrm{g} / \mathrm{L}$, or $2 \mathrm{mg} / \mathrm{L}$. The concentration gradient was chosen based on the following two considerations. The minimum concentration was based on the concentration at which antibiotics are usually detected. The highest concentration was the concentration that may cause obvious changes in swimming ability based on the results of preliminary experiments. All fish were fed twice per day in line with the adaptation period. The erythromycin solution in the water tank was replaced once per day to prevent changes in concentration due to photolysis and evaporation. 
After $96 \mathrm{~h}$ of exposure, experimental fish from each treatment group were randomly selected to measure $\mathrm{U}_{\text {crit }}$ or $\mathrm{U}_{\text {burst }}$. Moreover, the mRNA of muscle and head was extracted from the experimental fish (control group and $2 \mathrm{mg} / \mathrm{L}$ treatment group). Each test concentration and the control were performed in triplicate.

\subsection{Measurement of $U_{\text {crit }}$ and $U_{\text {burst }}$}

The equipment used to measure fish swimming ability was a medium-sized swimming tank (SW10150) produced by Loligo Systems (Denmark). The volume of the sealing part of the sink was $30 \mathrm{~L}$. The test area specifications were $55 \mathrm{~cm} \times 14 \mathrm{~cm} \times 14 \mathrm{~cm}$, and the flow rate of the test area ranged from 5 to $175 \mathrm{~cm} / \mathrm{s}$. The flow rate in the sealed sink was generated by the rotation of a motor, which could be changed by adjusting the drive, while the regulator was connected by the inverter and the cellular stabilizer on the left side of the test area to produce a uniform and constant flow field. In addition, a YSI Ecosense D0200A dissolved oxygen meter, digital flow speedometer (AC10000) and $30 \mathrm{~mm}$ vane wheel flow probe (AC10002) were used.

Before the start of the test, the dissolved oxygen level and temperature conditions in the device were checked, and the motor was gradually turned to remove bubbles from the test device. Then, a D. rerio was placed in the test area of the swimming device, and the test device was sealed. The flow rate was adjusted to $10 \mathrm{~cm} / \mathrm{s}$ and then increased by $25 \mathrm{~cm} / \mathrm{s}$ at $20 \mathrm{~min}$ intervals. For O. latipes, the flow rate was increased to $15 \mathrm{~cm} / \mathrm{s}$ over $20 \mathrm{~min}$ and then increased by $10 \mathrm{~cm} / \mathrm{s}$ every $20 \mathrm{~min}$. Finally, an experimental fish swimming fatigue net was used to end the test. The following formula was used to calculate $U_{\text {crit }}$ :

$$
U_{c r i t}=v_{2}+\frac{t_{2}}{\Delta t_{2}} \Delta v_{2}
$$

where

$\Delta t_{2}(\mathrm{~min})$ is the duration of each flow rate, $t_{2}(\mathrm{~min})$ is the time the test fish remained at this flow rate, $\Delta v_{2}(\mathrm{~cm} / \mathrm{s})$ is the velocity increment, and $v_{2}(\mathrm{~cm} / \mathrm{s})$ is the maximum swimming speed of the test fish that was reached during $\Delta v_{2}$.

At the end of the experiment, the flow rate was decreased, the fatigued test fish were removed, and their body length, weight and conventional morphological parameters were measured. During the test, if the dissolved oxygen concentration in the sink was less than $7 \mathrm{mg} / \mathrm{L}$, the water in the sealed sink was exchanged with a water pump.

$\mathrm{U}_{\text {burst }}$ was also calculated according to the "incremental flow rate method". A fish was placed in the test segment before the test and was adapted to a low flow rate $(10 \mathrm{~cm} / \mathrm{s})$ for $20 \mathrm{~min}$ to eliminate the stress of the transfer process on the fish. After the test started, the flow rate in the test segment was gradually increased by $1 \mathrm{~cm} / \mathrm{s}$. When the test fish were fatigued and could not continue to swim, the test was stopped. The critical swimming ability and burst swimming ability tests were repeated three times.

\subsection{RNA Sequencing}

Experimental fish from the control group and the $2 \mathrm{mg} / \mathrm{L}$ treatment group were randomly selected and placed in MS222 at a concentration of $0.2 \mathrm{mg} / \mathrm{L}$ until anesthetized. The tail muscle tissue and head tissue were collected, processed and immediately placed in liquid nitrogen. The processed samples were then sent to Nanjing Personal Gene Technology Company for RNA determination and sequencing.

Total RNA was isolated with a RNeasy Mini Kit (Qiagen, Germantown, MD, USA). Then, additional DNase I (Qiagen) was added to digest contaminating genomic DNA. One microgram of integrated RNA per sample was prepared and sequenced using an RNA-Seq library. The mRNA library was built by the TruSeq RNA Sample Preparation Kit (Illumina, San Diego, CA, USA) with reference to the manufacturer's instructions. The prepared mRNA samples were then clustered on an Illumina HiSeq 2500 for sequencing. The sequences from each treatment group were evaluated after 
100 cycles. The RNA-Seq reads were assessed for quality control with FastQC (version 0.10.1; Babraham Bioinformatics, Cambridge, UK). All reads were evaluated by Bridger (r2014-12-01) (-pair_gap_length 50-min_kmer_coverage 4-min_ratio_non_error 0.15). The transcripts scored per million fragments per thousand bases of external subfragments mapped (RSM) were calculated according to Trinity script variance expression (false discovery rate $(F D R) \leq 0.05$ ) using the blind dispersion method and Cuffdiff analysis, which yielded lists of upregulated and downregulated genes. Fisher's exact test with FDR correction (FDR $\leq 0.05)$ was used to analyze gene functions and pathways by Gene Ontology (GO) functions and Kyoto Encyclopedia of Genes and Genomes (KEGG) pathways, respectively. The ratio of differentially expressed genes (DEGs) to the total number of genes in the associated pathways was considered an enrichment factor.

\subsection{Quantitative Real-Time PCR ( $q$ RT-PCR) Validation}

qRT-PCR was used to verify the results of RNA-Seq. Based on their position, function and expression level in the genome, eight differentially expressed transcripts were selected (6 upregulated and 2 downregulated). mRNA transcripts were aliquoted using a RealPlex4S qRT-PCR system (Eppendorf, Germany). RNA samples were extracted using an miRNeasy Mini Kit (50) (Qiagen). The final volume of the RT-PCR reaction was $25 \mu \mathrm{L}$. The thermocycler settings were as follows: $95^{\circ} \mathrm{C}$, $2 \mathrm{~min}$; and 40 cycles of $95^{\circ} \mathrm{C}$ for $10 \mathrm{~s}, 68^{\circ} \mathrm{C}$ for $30 \mathrm{~s}$, and $68^{\circ} \mathrm{C}$ for $5 \mathrm{~min}$. The relative expression level was calculated using the $2^{-\Delta \Delta C T}$ method with $\beta$-actin as a reference gene. Three independent samples were analyzed in triplicate.

\subsection{Statistical Analyses}

The $U_{\text {crit }}$ and $U_{\text {burst }}$ of experimental fish were analyzed with Origin 8.0 software (Origin Lab Corporation, Northampton, MA, USA) and SPSS Statistics 20 (SPSS Inc., Chicago, IL, USA). Significant differences between the treatment groups were determined with one-way analysis of variance (ANOVA), and the significance level was set at $p<0.05$. Transcriptomic data were analyzed and visualized by $R$ software (Core Team, 2014).

\subsection{Ethics Statement}

The animal study proposal was approved by the Ethics Committee for Animal Experiments of Sichuan University (ethics code is 2019062101). All experimental procedures were performed in accordance with the Regulations for the Administration of Affairs Concerning Experimental Animals approved by the State Council of the People's Republic of China.

\section{Results}

\subsection{Swimming Performance and Muscle Fibers}

The $U_{\text {crit }}$ of $D$. rerio and O. latipes after $96 \mathrm{~h}$ of exposure to varying doses of erythromycin $(2 \mu \mathrm{g} / \mathrm{L}$, $20 \mu \mathrm{g} / \mathrm{L}, 200 \mu \mathrm{g} / \mathrm{L}$, and $2 \mathrm{mg} / \mathrm{L}$ ) is illustrated in Figure 2a,c. The $U_{\text {crit }}$ of D. rerio was decreased by a small margin in the low-concentration treatment groups $(2 \mu \mathrm{g} / \mathrm{L}, 20 \mu \mathrm{g} / \mathrm{L}$ and $200 \mu \mathrm{g} / \mathrm{L})$. In addition, the $\mathrm{U}_{\text {crit }}$ of $D$. rerio decreased markedly to $14.17 \mathrm{BL} / \mathrm{s}$ in the high-concentration treatment group $(2 \mathrm{mg} / \mathrm{L})$ compared with the control group $(26.32 \mathrm{BL} / \mathrm{s})\left(\mathrm{U}_{\text {crit }}: \mathrm{df}=3, \mathrm{~F}=5.32, p=0.03\right)$; the lowest dose of erythromycin $(2 \mu \mathrm{g} / \mathrm{L})$ slightly decreased the speed of O. latipes to $15.25 \mathrm{BL} / \mathrm{s}$, and the highest dose of erythromycin $\left(2 \mathrm{mg} / \mathrm{L}\right.$ ) clearly reduced the $U_{\text {crit }}$ value of $O$. latipes to $10.32 \mathrm{BL} / \mathrm{s}$, while the $\mathrm{U}_{\text {crit }}$ of the control fish was $15.46 \mathrm{BL} / \mathrm{s}$. 


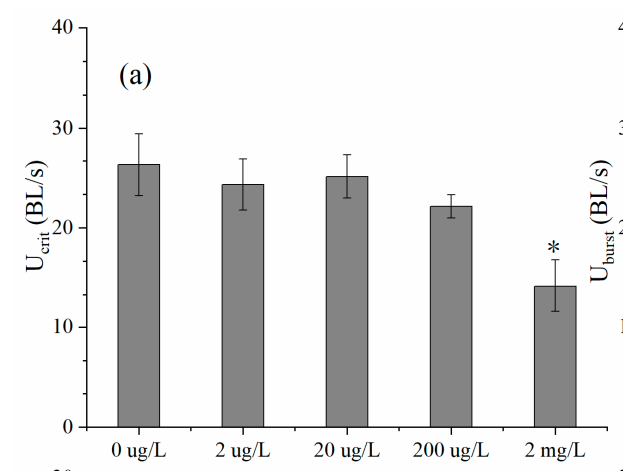

(b)
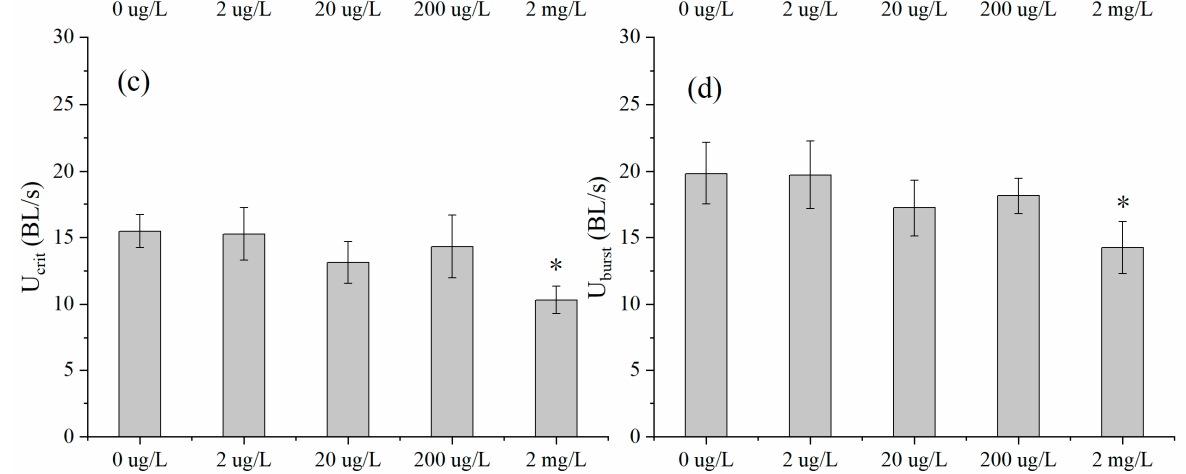

Figure 2. (a) Critical swimming speed $\left(\mathrm{U}_{\text {crit }}\right)$ and (b) burst speed ( $\mathrm{U}_{\text {burst }}$ ) of Danio rerio; (c) $\mathrm{U}_{\text {crit }}$ and (d) $U_{\text {burst }}$ of Oryzias latipes exposed to varying concentrations $(0 \mu \mathrm{g} / \mathrm{L}, 2 \mu \mathrm{g} / \mathrm{L}, 20 \mu \mathrm{g} / \mathrm{L}, 200 \mu \mathrm{g} / \mathrm{L}$, and $2 \mathrm{mg} / \mathrm{L}$ ). Significant differences between the control groups and erythromycin exposed groups, * repersents $p<0.05$.

The $\mathrm{U}_{\text {burst }}$ of $D$. rerio and O. latipes is shown in Figure $2 \mathrm{~b}, \mathrm{~d}$. Although the $\mathrm{U}_{\text {burst }}$ of $D$. rerio improved slightly under treatment with low doses of erythromycin $(2 \mu \mathrm{g} / \mathrm{L}$ and $20 \mu \mathrm{g} / \mathrm{L})$, there was a striking overall downward trend with increased doses of erythromycin. The $\mathrm{U}_{\text {burst }}$ of $D$. rerio (20.12 BL/s and $16.57 \mathrm{BL} / \mathrm{s}$ ) was dramatically lower in the $200 \mu \mathrm{g} / \mathrm{L}$ and $2 \mathrm{mg} / \mathrm{L}$ group than in the control group $(27.12 \mathrm{BL} / \mathrm{s})\left(\mathrm{U}_{\text {burst }}: \mathrm{df}=3, \mathrm{~F}=2.45, p=0.03\right)\left(\mathrm{U}_{\text {burst }}: \mathrm{df}=3, \mathrm{~F}=4.28, p=0.04\right)$; The $\mathrm{U}_{\text {burst }}$ of O. latipes fluctuated with increasing doses of erythromycin from $2 \mu \mathrm{g} / \mathrm{L}$ to $200 \mu \mathrm{g} / \mathrm{L}$, but the $\mathrm{U}_{\text {burst }}$ value $(14.23 \mathrm{BL} / \mathrm{s})$ was notably lower in the $2 \mathrm{mg} / \mathrm{L}$ group than in the nonexposed group $(19.84 \mathrm{BL} / \mathrm{s})$ $\left(\mathrm{U}_{\text {burst }}: \mathrm{df}=4, \mathrm{~F}=3.65, p=0.02\right)$.

The appearance of the exposed fish and the appearance of the control group were not observed to be different. the size of the muscle fibers changed significantly, as shown in Figure 3. The muscle fibers of $D$. rerio and O. latipes became thinner and weaker. Additionally, the pores of the muscle fiber bundle also became larger following erythromycin-induced stress. 

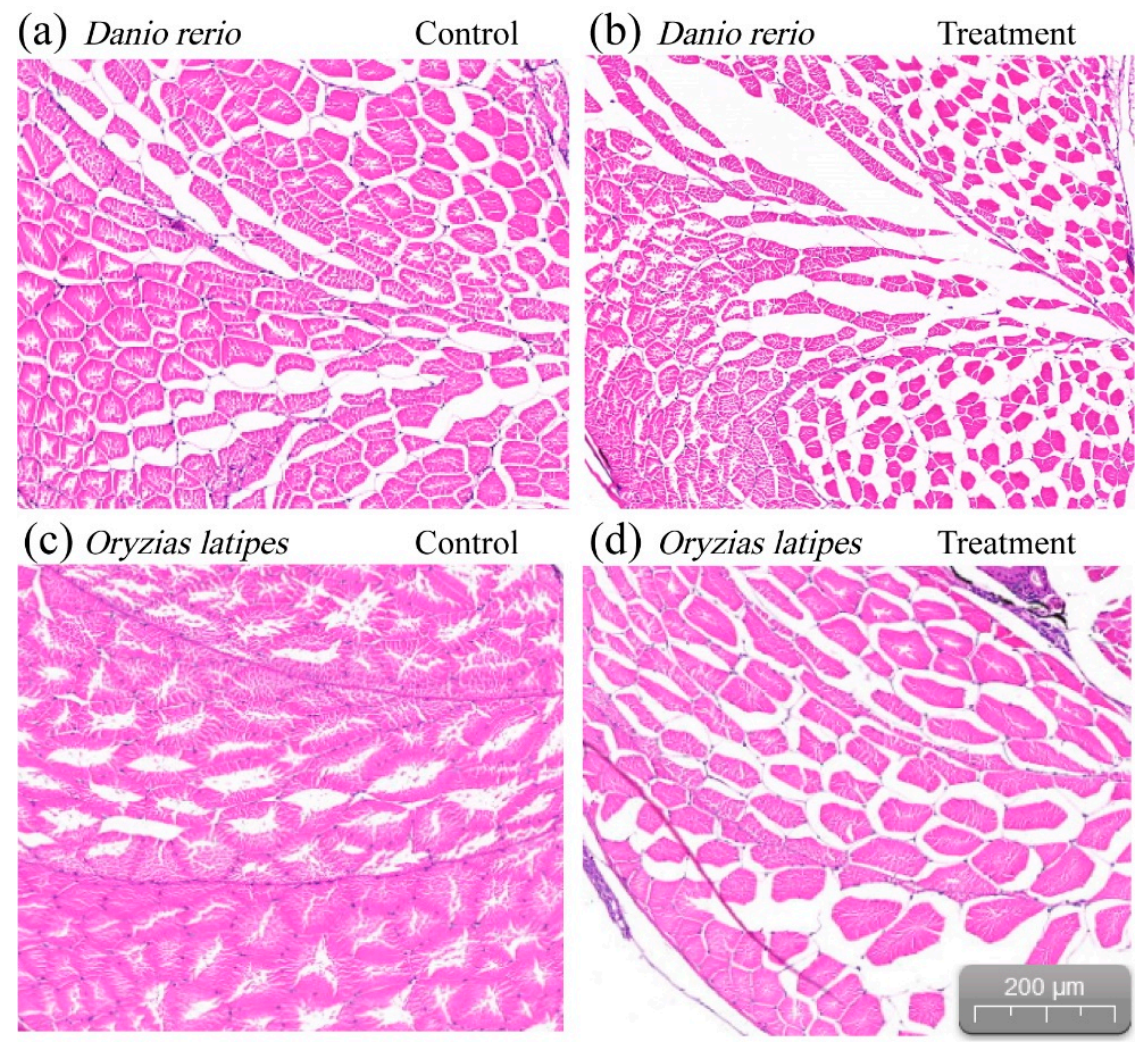

Figure 3. Thinner and weaker muscle fibers bundles exposed to $2 \mathrm{mg} / \mathrm{L}$. (a) and (b) of D. rerio; (c) and (d) of O. latipes.

\section{2. $m R N A$ Expression Levels of Genes}

Deep sequencing data were analyzed for each obtained sample from the treatment groups. We considered read quality scores above Q30 (correct base recognition rate greater than $99.9 \%$ ) to indicate clean reads, and the muscle gene expression results of the experimental fish showed that more than $94.2 \%$ of the $D$. rerio reads were clean, while more than $93.4 \%$ of the O. latipes reads were clean. The proportion of mapped reads in D. rerio sequences was higher than $97.86 \%$, and was higher than $94.09 \%$ in O. latipes. With erythromycin treatment, there were 503 upregulated genes and 541 downregulated genes in O. latipes muscle, while 463 upregulated and 319 downregulated genes were found in the muscle of $D$. rerio, as shown in Figure 3.

To gain a better understanding of the effects of erythromycin on genes in D. rerio muscles, we further analyzed the KEGG pathways. Based on the KEGG enrichment analysis of the expressed genes, the top 20 pathways with the smallest $p$-values, indicating the most significant enrichment, were selected for presentation, as shown in Figure 4. The most significant KEGG pathway in D. rerio and O. latipes was oxidative phosphorylation. Specifically, D. rerio had 47 downregulated genes (cox6a2, ndufs6, cox5b2 etc.), and O. latipes had 53 downregulated genes (ndufs4, ndufa12, ndufb3 etc.).

The gene expression profiles of the heads of the experimental fish showed that $D$. rerio had more than $93.13 \%$ clean reads and O. latipes had more than $92.7 \%$. The proportion of mapped reads in the D. rerio sequences was higher than $95.1 \%$, and the proportion of mapped reads in O. latipes was more than $94.09 \%$. Genes in the fish head were impacted by erythromycin treatment, and there were 342 upregulated genes and 1106 downregulated genes in the head of O. latipes. For D. rerio, 461 genes were upregulated, and 551 genes were downregulated, as shown in Figure 5. 
(a)

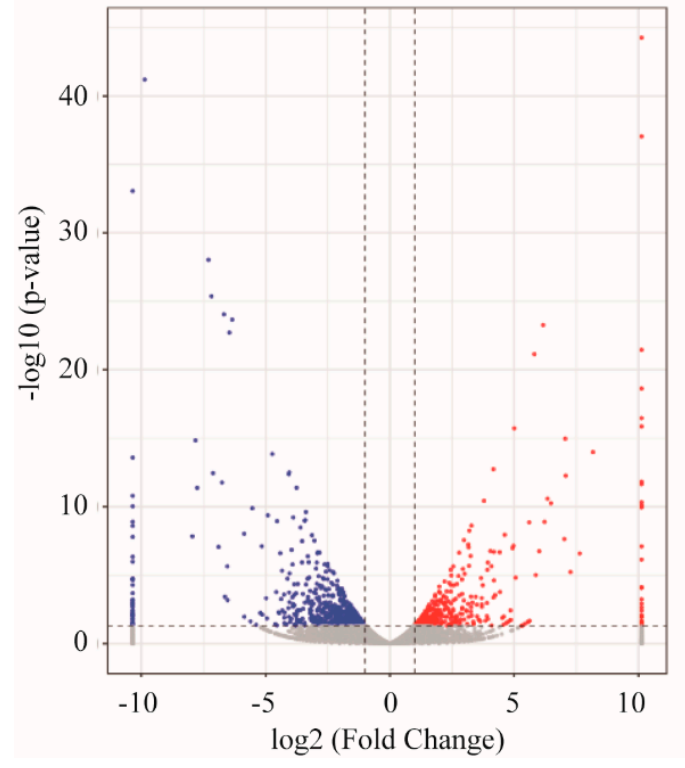

(b)

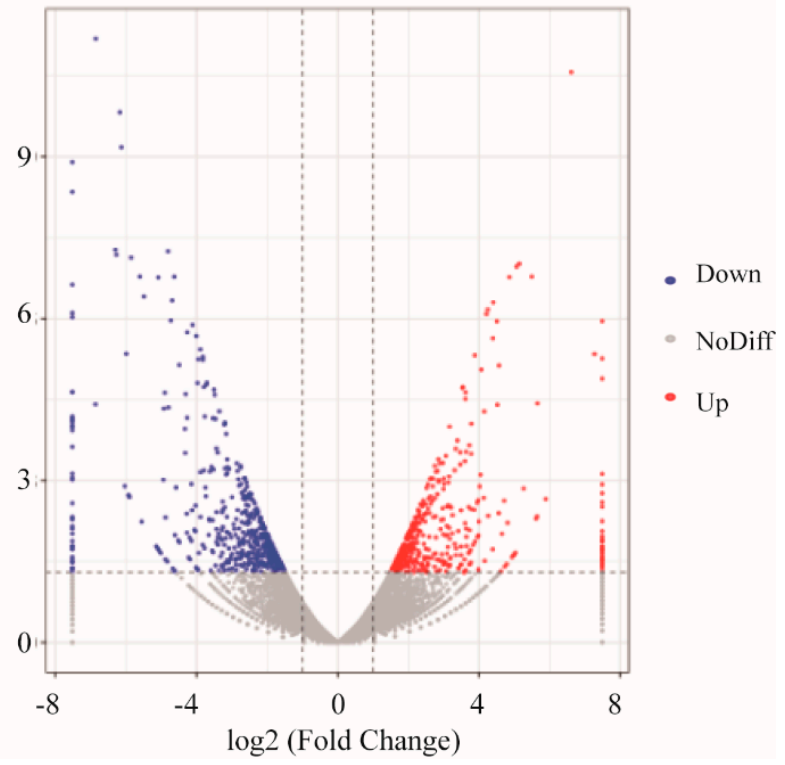

Figure 4. Volcano plots of the gene libraries of muscle from fish in the antibiotic-treated groups and control group showing the variance in gene expression with respect to FC and FDR. Each dot represents an individual gene: the black dots on the left represent the downregulated genes, and the red dots on the right represent the upregulated genes (a) D. rerio, (b) O. latipes.

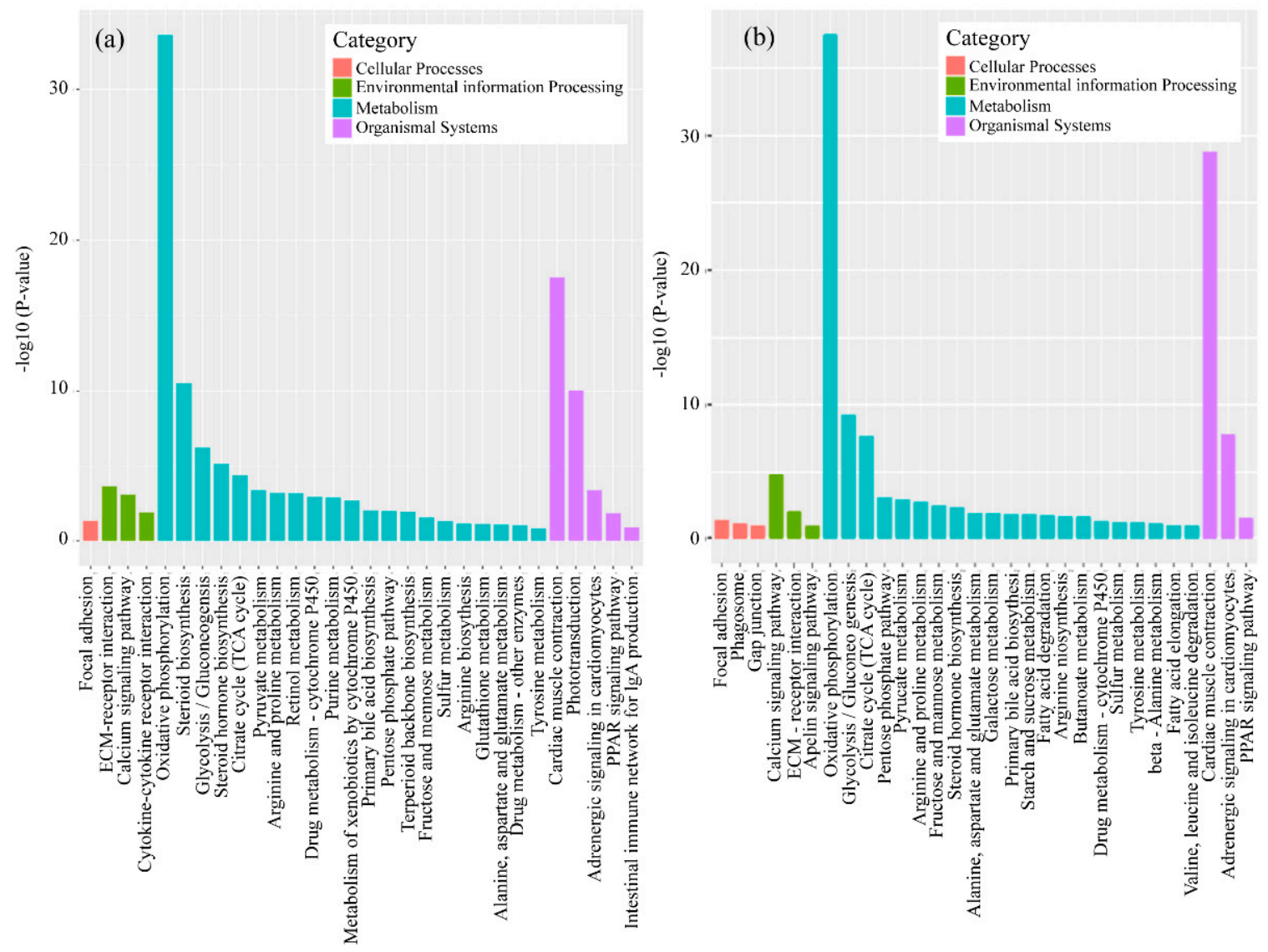

Figure 5. The top 20 enriched Kyoto Encyclopedia of Genes and Genomes (KEGG) pathways in the erythromycin-treated groups and the control group (a) D. rerio, (b) O. latipes. 
To obtain insight into the alteration in gene expression in the head of $D$. rerio induced by erythromycin, KEGG pathways were analyzed. We selected the top 20 pathways with the smallest $p$-values and the most significant enrichment for presentation based on KEGG pathway enrichment analysis, as presented in Figure 6. For O. latipes, the KEGG analysis results showed that the two most significant pathways in organismal systems were the adipocytokine signaling pathway (npy and ppara) and the PPAR signaling pathway (lpl). In addition, for D. rerio, the most significant pathway in the organismal systems category was phototransduction (guca1a, grk7b and grk1a).

(a)

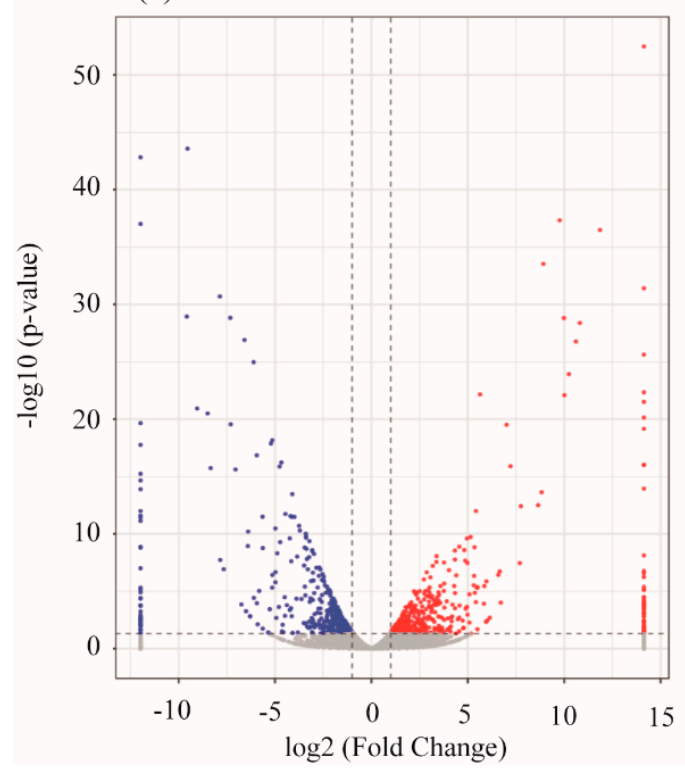

(b)

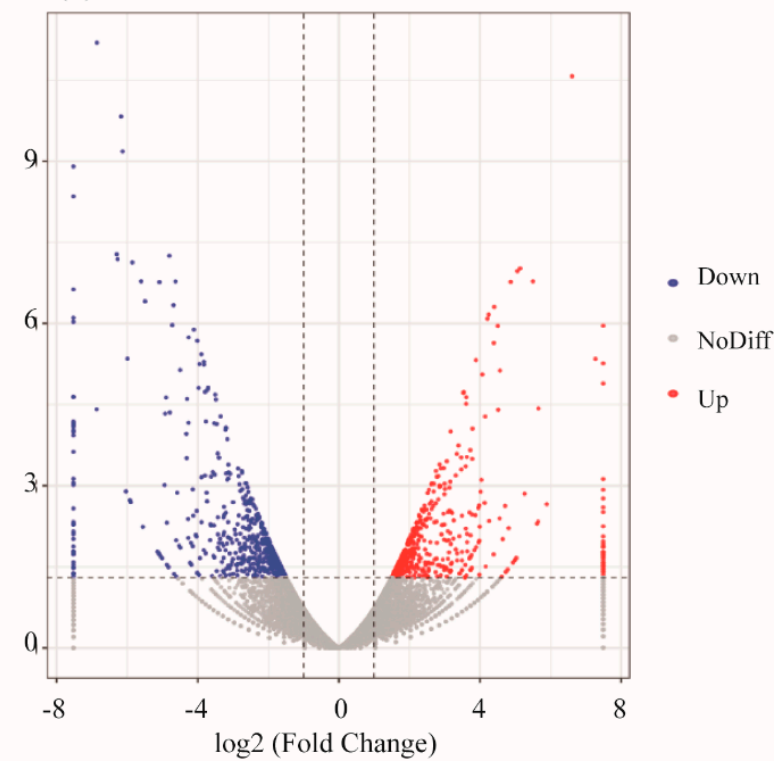

Figure 6. Volcano plots of the gene libraries of heads from experimental fish in the antibiotic-treated groups and control group showing the variance in gene expression with respect to FC and FDR. Each dot represents an individual gene: the black dots on the left represent the downregulated genes, and the red dots on the right represent the upregulated genes (a) D. rerio, (b) O. latipes.

\subsection{Validation of RNA-Seq DEG Expression Profiles in Danio rerio and Oryzias latipes by qRT-PCR}

Fifteen DEGs in the RNA-Seq results were selected for expression pattern verification by qRT-PCR using cDNA from the remaining RNA samples from the different erythromycin treatment groups. These 15 genes were identified in the D. rerio head (4 DEGs) and muscle (4 DEGs) or in the O. latipes head (3 DEGs) and muscle (4 DEGs). The 15 genes reported in the RNA-Seq data (2 upregulated and 13 downregulated) are shown in Figure 7 . All of these genes were significantly changed in the high-concentration exposure group compared with the control group because the adverse effects were amplified. However, at low concentrations, these genes had unstable expression patterns. Nevertheless, all of these genes were significantly changed in the same direction as in the other groups, which verified the results of RNA-Seq (Figure 8). 

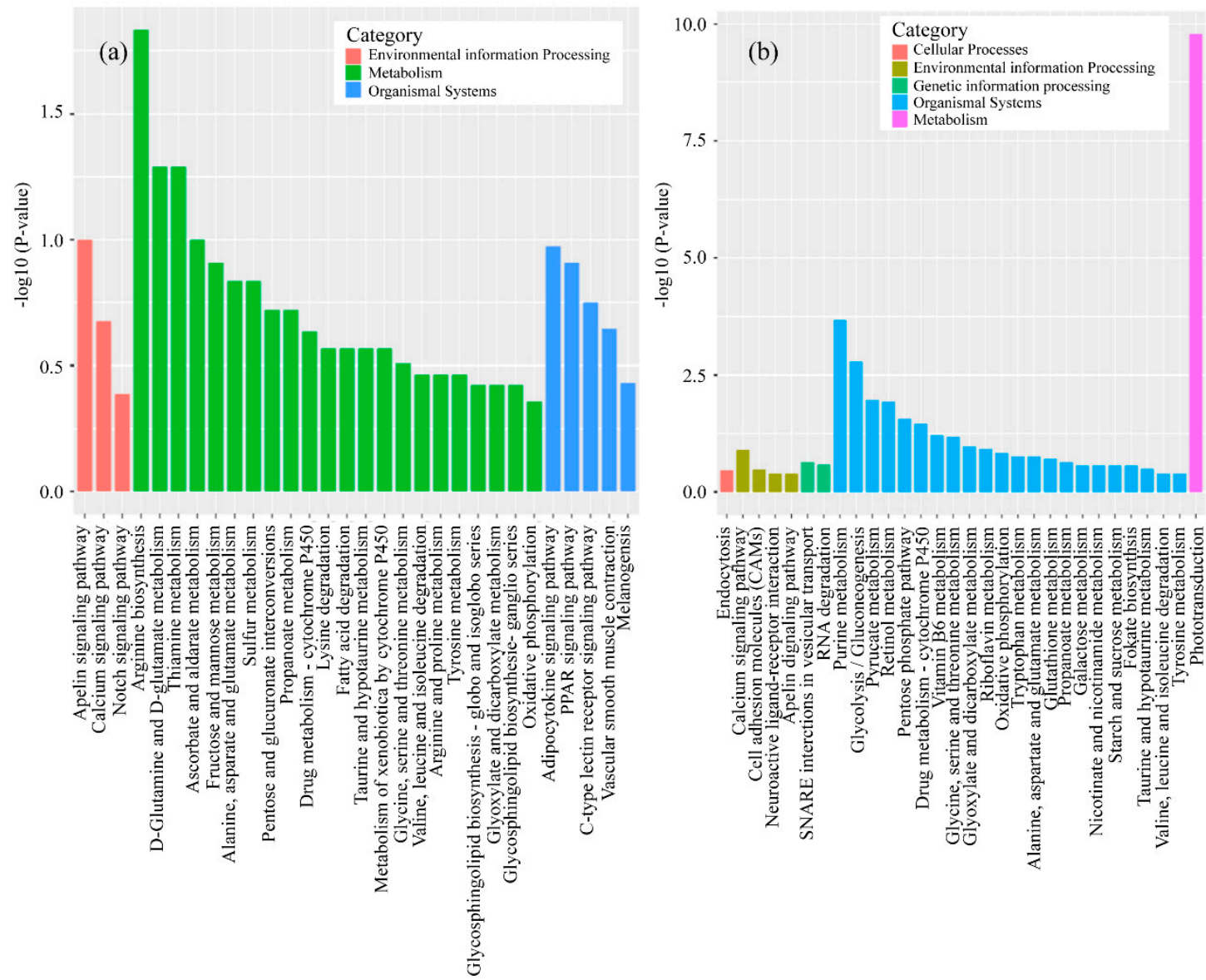

Figure 7. The top 20 enriched KEGG pathways in the erythromycin-treated groups and the control group (a) D. rerio, (b) O. latipes.
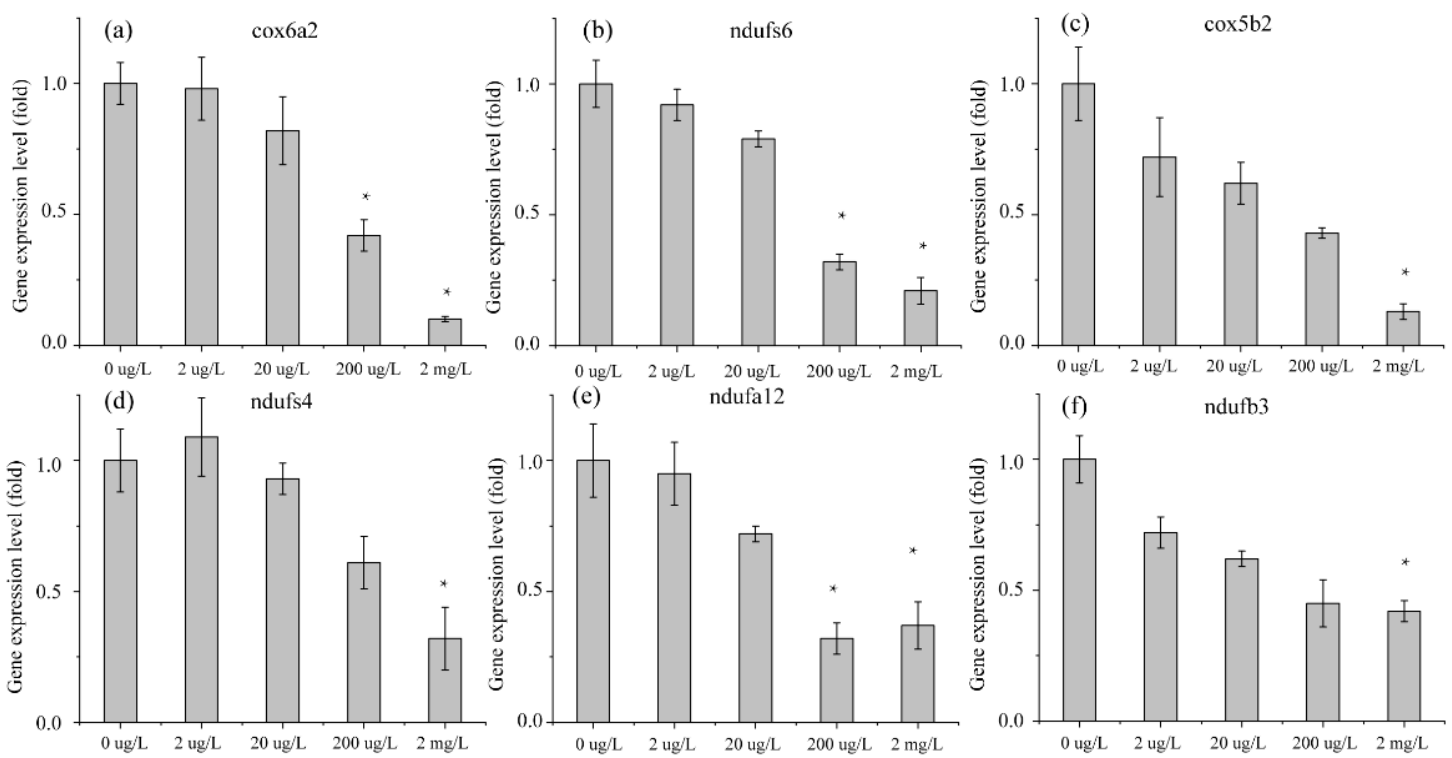

Figure 8. Cont. 

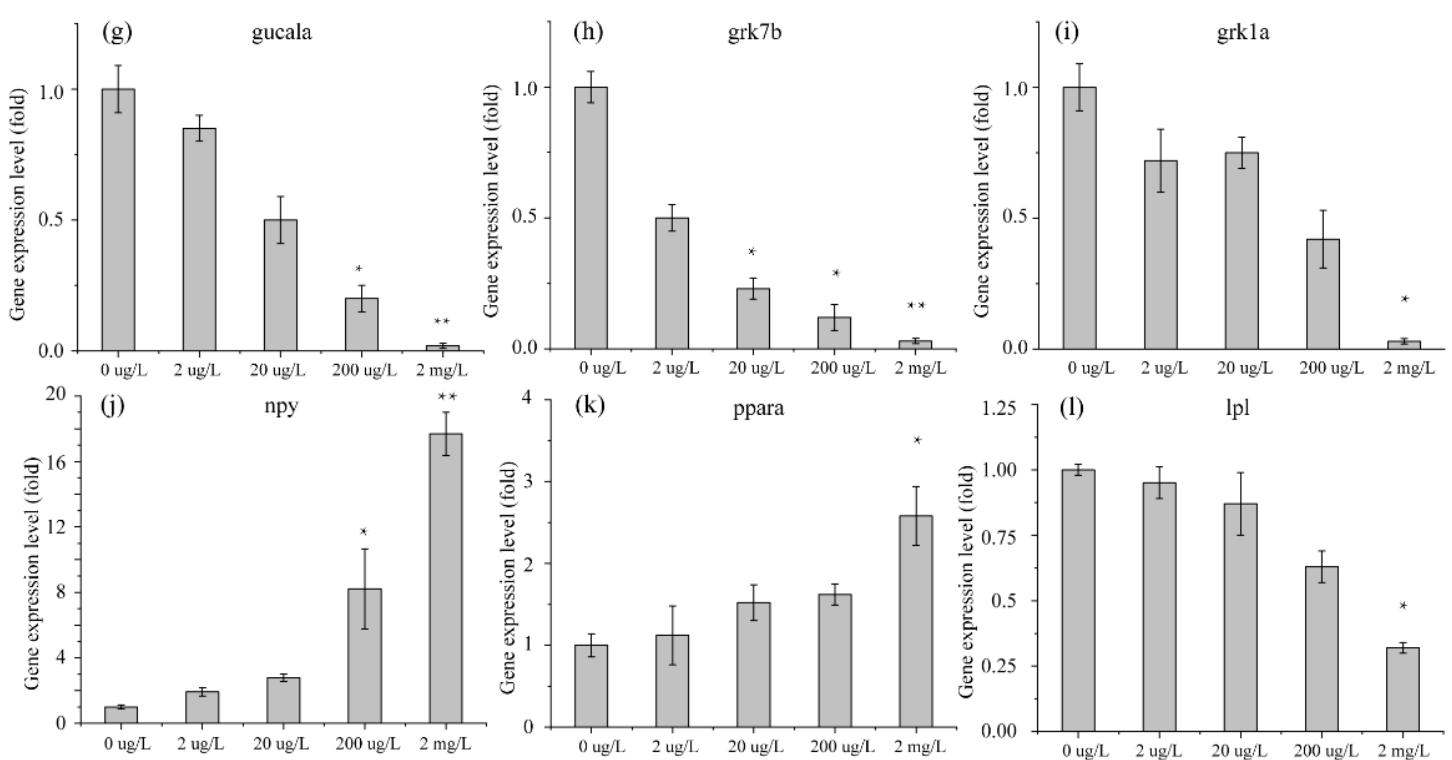

Figure 8. The effects of erythromycin on the mRNA expression of genes in D. rerio and O. latipes. $((\mathbf{a}-\mathbf{c})$ gene in D. rerio's muscle; $(\mathbf{d}-\mathbf{f})$ gene in O. latipes's muscle; $(\mathbf{g}-\mathbf{i})$ gene in D. rerio's head; $(\mathbf{j}-\mathbf{1})$ gene in O. latipes's head) Values represent the mean $\pm \mathrm{SD}\left(\mathrm{n}=3\right.$ replicates). ${ }^{*}$ indicates $p<0.05$ relative to the control.

\section{Discussion}

\subsection{Swimming Performance}

Antibiotics had a greater negative effect on the $\mathrm{U}_{\text {crit }}$ of $D$. rerio than on that of $O$. latipes. The $\mathrm{U}_{\text {crit }}$ of both species was significantly impaired at high exposure concentrations. Other environmental pollutants have been shown to reduce the swimming ability of other species of fish. For example, the $U_{\text {crit }}$ of juvenile Florida pompano was significantly reduced from $90.10 \pm 1.35 \mathrm{~cm} / \mathrm{s}$ to $84.20 \pm 1.36 \mathrm{~cm} / \mathrm{s}$ under the toxic influence of methanol [24]. Another study found that $\mathrm{U}_{\text {crit }}$ of Erimyzon sucetta was reduced by approximately $50 \%$ when they were exposed to ash [25]. Prolonged swimming activities (such as $\mathrm{U}_{\text {crit }}$ ) may be sensitive to changes in maximum aerobic capacity, cardiac output, muscle fiber function, and anaerobic metabolism. The results showed that the aerobic capacity of the fish was impaired. There are several possible reasons for this impairment. Fish are poisoned by environmental pollutants and are forced to detoxify a large amount of oxygen [26,27], which reduces the oxygen supplied for exercise [27]. In addition, water pollution can change the shape of gill tissue, resulting in an impaired tissue oxygen supply during exercise [28,29]. Moreover, sublethal exposure to contaminating elements can also lead to increased hemoglobin and plasma protein concentrations, resulting in increased blood concentrations and local tissue hypoxia [30].

The $\mathrm{U}_{\text {burst }}$ of D. rerio and O. latipes showed decreases of $38 \%$ and $31 \%$, respectively, under treatment with $2 \mathrm{mg} / \mathrm{L}$ erythromycin. Explosive activity occurs rapidly in a short period of time, and burst swimming performance is mainly affected by anaerobic metabolism; thus, some functions related to anaerobic metabolism in both species may be hindered. $U_{\text {burst }}$ reflects the ability of a fish to perform short-term anaerobic movements while foraging or avoiding danger [31]. This result reveals that the ability of experimental fish to hunt and evade predators was weakened, which may reduce the survival rate of experimental fish in the long run. Previous studies have also found that toxic contamination can adversely affect the $\mathrm{U}_{\text {burst }}$ of fish. For instance, the $\mathrm{U}_{\text {burst }}$ of ash-exposed E. sucetta was decreased by $30 \%-104 \%$ compared to that of control fish [25-27].

The swimming performances of $D$. rerio and O. latipes were weakened by $2 \mathrm{mg} / \mathrm{L}$ erythromycin. Our results indicate that the weakening of the muscle fibers of the experimental fish is a possible reason for the decline in swimming ability. Previous studies on toxin exposure can lead to body dysfunction 
and muscle structure [32]. Under the treatment of contaminants, zebrafish somatic muscle fibers affect the arrangement or integrity of muscles, and the abnormality of muscles directly affects exercise ability. Specifically, the impairment of myogenesis and the destruction of myofilament tissue caused by contaminants impedes the ability of muscles to contract and thus significantly reduces swimming performance of zebrafish [33]. Another possible reason is that aerobic and anaerobic metabolism is regulated by different physiological mechanisms, and the results of the swimming ability assay showed that erythromycin had adverse effects on these two physiological mechanisms. The effect of other antibiotics on fish mobility also supports these results. Studies showed that high concentrations of antibiotics, even for short periods of time, can induce behavioral disturbances in fish [34]. Both aerobic and anaerobic metabolic capacities were inhibited by erythromycin exposure. This suggests that erythromycin affects the energy metabolism of fish.

\subsection{Analysis of $m R N A$ in Muscle}

Swimming behavior is closely related to muscle contraction. A decline in swimming ability reflects a decline in muscle function. Moreover, aerobic metabolism involves the transport of oxygen and carbohydrates through respiration and circulation. It reflects the metabolic processes throughout the organism, from skin to muscle tissue, which may affect the absorption and transport of oxygen. Additionally, aerobic activity requires a continuous supply of adenosine triphosphate (ATP) from fish in different organs and muscles [34,35]. Anaerobic movement is a temporary explosion with a limited range of rapid metabolism [36]. It allows carbohydrates and oxygen to enter the muscle, which consumes glycogen and phosphocreatine during explosive movement. The power of anaerobic activity depends on ATP in the absence of oxygen $[37,38]$. Both types of exercise depend on the ability of muscles to produce and release ATP. The mRNA expression results of the muscles from both species confirm their behavior and further explain the decline in swimming ability.

The markedly enriched KEGG pathway shown in Figure 4 was oxidative phosphorylation. Additionally, both species had downregulated genes in this pathway, which suggests that the energy metabolism of $D$. rerio and $O$. latipes was inhibited by erythromycin. Oxidative phosphorylation is a metabolic pathway in cells. This process occurs in the mitochondrial inner membrane of eukaryotes or in the cell membrane of prokaryotes and uses the enzymes and the energy released by the oxidation of various nutrients to synthesize ATP. ATP is the primary molecule that directly provides energy to anabolic organisms. For most aerobic organisms, the tricarboxylic acid cycle-oxidative phosphorylation is the main process that produces ATP. The first four significantly altered genes in this pathway in D. rerio and O. latipes were validated. In addition, these genes encode NADH dehydrogenase, cytochrome c oxidases, and F-type ATPase (eukaryotes). NADH dehydrogenase is used in the electron transport chain to generate ATP. It is a receptor oxidoreductase that catalyzes the following chemical reactions: $\mathrm{NADH}+\mathrm{H}++$ acceptor $\rightleftharpoons \mathrm{NAD}++$ reduced acceptor [39]. Cytochrome c oxidases have beneficial effects on exercise, such as increasing oxygen levels in vascular tissues. Enzymes cannot reduce oxygen, resulting in oxygen accumulation and the diffusion of oxygen into surrounding tissues [40]. The downregulation of this gene means the loss of these beneficial effects. Another study suggested that the suppression of cytochrome c oxidases decreases the rate of cellular respiration [41]. F-ATPase, also known as F-Type ATPase, is involved in many basic cellular metabolic activities (such as acidosis, alkalosis and respiratory gas exchange). The gene expression results provide an explanation for the decrease in the swimming ability of $D$. rerio and O. latipes under erythromycin stress. Antibiotics adversely affected the energy metabolism pathways of these two fish. Specifically, ATP synthesis and ATP release were inhibited, which inevitably damaged their swimming ability.

\subsection{Analysis of mRNA in Head}

Muscle energy supply is directly related to swimming behavior, and the central nervous system can also indirectly negatively impact fish swimming ability. Abnormal functions related to the central nervous system may cause sensory organ dysfunction and movement disorders. It can also 
lead to hormone disorders that block energy metabolism. The sensitivity of fish to stress induces changes in behavior, and the fields of behavioral ecology and toxicology provide a clear explanation of this connection. Biochemical disorders, such as neurotransmitter and thyroid changes, affect the behavior of fish [42]. D. rerio phototransduction was subdued under the pressure of erythromycin. Phototransduction is the conversion of the distribution and wavelength of photons into neuron activity patterns, which then induce movement and endocrine responses. In D. rerio and in mice with mutations in a light-sensing gene, researchers found both motor and motor coordination mutations $[43,44]$. The optokinetic response (OKR) requires the retina as a photosensitive organ and employs motor thrust, as does swimming $[43,44]$. Mutant $D$. rerio have slow eye movement and impaired motor ability [45]. In addition to the extreme situation, a more common phototransduction function is to regulate circadian rhythm through visual pigments [46]. Impaired light transmission can disrupt the body clock, which reverses day and night and affects metabolism. The mRNA expression results from the head of O. latipes revealed neuroendocrine disruption under the pressure of erythromycin. Biological neuroendocrine systems are used to regulate food intake, metabolism, and energy distribution to ensure a steady supply of energy [46,47]. Metabolism and aerobic exercise are intertwined because of a common connection: they both depend on the intake of food, which is the source of chemical energy for these processes. In the short term, there is a match between energy intake and expenditure. In the long term, they are carefully balanced and regulated by several endocrine systems that work together to ensure energy homeostasis [48,49]. The hypothalamus is crucial for monitoring energy balance [50]. The hypothalamus regulates energy by signaling fat storage. Another theory is that the hypothalamus regulates energy balance by storing signals from carbohydrates [51].

The most affected biological system in $D$. rerio was phototransduction, a sensory transduction pathway in the visual system. Through this process, light is converted into electrical signals in the rods, cones, and photosensitive ganglion cells of the retina in the eye. In the dark, the main function of the downregulated genes is to control the transmission of $\mathrm{Ca}^{2+}$ ions, thereby inhibiting neurotransmitters. In light, the downregulated genes primarily affect the function of retinal porphyrin. The inactivation of rhodopsin may cause the loss of dark adaptation. These downregulated genes indicate that the vision of $D$. rerio is impaired in light and darkness, and that visual adaptability is damaged when light and dark alternate. The visual sensitivity of fish to light and dark requires much energy [52], but phototransduction is very important for fish to hunt and avoid danger. D. rerio had weakened visual ability under the pressure of erythromycin, which means that the chances of survival were reduced. In addition to erythromycin, other environmental pollutants may also cause the visual function of fish to be suppressed. For example, tributyltin has also been reported to block this pathway in fish [53].

For O. latipes, the upregulated genes related to a biological system were Neuropeptide Y (NPY) and PPAR- $\alpha$. NPY is a 36 amino acid neuropeptide that participates in various physiological processes and in the homeostasis of the central nervous system and peripheral nervous system [54-57]. In the head, NPY is produced in different parts of the hypothalamus. In addition, NPY is thought to have multiple functions, including changing the storage of fat energy and reducing anxiety and stress [57,58]. NPY regulates the neuroendocrine release of various hypothalamic hormones, such as luteinizing hormone [59]. In particular, NPY is considered to be an endogenous anxiolytic peptide. The level of NPY can be regulated by stress, and it is considered necessary for stress regulation [60]. Higher levels of NPY may be self-regulating to alleviate fear responses [61]. The upregulation of NPY in O. latipes is a sign of fear and anxiety. In addition, there may be disorders in fat metabolism. PPAR is an important transcription factor. PPAR- $\alpha$ regulates many genes involved in various aspects of lipid metabolism. The upregulation of this gene may activate functions related to lipid metabolism. However, the downregulation of $\mathrm{Lpl}$ demonstrates that fatty acid transport and a component of lipid metabolism was inhibited [62]. That means erythromycin can cause many lipoprotein metabolism abnormalities. 


\section{Conclusions}

The swimming ability of the Oryzias latipes and Danio rerio was measured after exposure to varying doses of erythromycin $(2 \mu \mathrm{g} / \mathrm{L}, 20 \mu \mathrm{g} / \mathrm{L}, 200 \mu \mathrm{g} / \mathrm{L}$, and $2 \mathrm{mg} / \mathrm{L})$ for $96 \mathrm{~h}$. $\mathrm{U}_{\text {burst }}$ and $\mathrm{U}_{\text {crit }}$ of the experimental fish did not change significantly at low concentrations $(2 \mu \mathrm{g} / \mathrm{L}, 20 \mu \mathrm{g} / \mathrm{L}, 200 \mu \mathrm{g} / \mathrm{L})$. The swimming ability of both $O$. latipes and $D$. rerio was reduced by exposure to high concentrations of erythromycin, and $U_{\text {crit }}$ decreased to $53 \%$ and $71 \%$, while $U_{\text {burst }}$ decreased by $39 \%$ and $23 \%$, respectively. This finding indicates that the aerobic capacity and anaerobic capacity of these fish were reduced. mRNA expression analysis of the muscle confirmed that ATP production- and ATP release-related functions were inhibited. Erythromycin has different effects on gene expression in the head of the two species, but the results from both species provide indirect evidence of behavioral changes. Phototransduction of $O$. latipes was inhibited, which may lead to abnormal behavior or body clock disorders. The hormone imbalance in O. latipes may lead to energy metabolism disorders, and its fat metabolism abnormalities.

Author Contributions: Conceptualization, J.Z. and Y.L.; methodology, Y.L.; validation, J.Z.; formal analysis, Y.L.; investigation, Y.L.; data curation, Y.L.; writing—original draft preparation, Y.L.; writing-review and editing, J.Z.; visualization, Y.L.; supervision, J.Z.; project administration, Y.L. All authors have read and agreed to the published version of the manuscript.

Funding: This work was supported by the National Key Project for Research and Development (2016YFC0401710).

Acknowledgments: The authors would like to thank the State Key Laboratory of Hydraulics and Mountain River Engineering, Sichuan University. They provided an instrument to test the swimming ability of fish and the technical support during the experiment.

Conflicts of Interest: The authors declare no conflict of interest.

\section{References}

1. Rodgers, C.J.; Furones, M.D. Antimicrobial agents in aquaculture: Practice, needs and issues. Options Méditerrané 2009, 86, 41-59.

2. Sapkota, A.; Sapkota, A.R.; Kucharski, M.; Burke, J.; McKenzie, S.; Walker, P.; Lawrence, R. Aquaculture practices and potential human health risks: Current knowledge and future priorities. Environ. Int. 2008, 34, 1215-1226. [CrossRef] [PubMed]

3. Ben, W.; Qiang, Z.; Adams, C.; Zhang, H.; Chen, L. Simultaneous determination of sulfonamides, tetracyclines and tiamulin in swine wastewater by solid-phase extraction and liquid chromatography-Mass spectrometry. J. Chromatogr. A 2008, 1202, 173-180. [CrossRef] [PubMed]

4. Armstrong, S.M.; Hargrave, B.T.; Haya, K. Antibiotic Use in Finfish Aquaculture: Modes of Action, Environmental Fate, and Microbial Resistance; Springer: Berlin/Heidelberg, Germany, 2005; pp. 341-357.

5. Fent, K.; Weston, A.A.; Caminada, D. Ecotoxicology of human pharmaceuticals. Aquat Toxicol. 2006, 76, 122-159. [CrossRef] [PubMed]

6. Zhang, Q.; Cheng, J.; Xin, Q. Effects of tetracycline on developmental toxicity and molecular responses in zebrafish (Danio rerio) embryos. Ecotoxicology 2015, 24, 707-719. [CrossRef] [PubMed]

7. Oliveira, R.; McDonough, S.; Ladewig, J.C.; Soares, A.M.; Nogueira, A.J.; Domingues, I. Effects of oxytetracycline and amoxicillin on development and biomarkers activities of zebrafish (Danio rerio). Environ. Toxicol. Pharm. 2013, 36, 903-912. [CrossRef] [PubMed]

8. Roberts, A.P.; Alloy, M.M.; Oris, J.T. Review of the photo-induced toxicity of environmental contaminants. Comp. Biochem. Physiol. Part C: Toxicol. Pharmacol. 2017, 191, 160-167. [CrossRef]

9. Nakano, T.; Hayashi, S.; Nagamine, N. Effect of excessive doses of oxytetracycline on stress-related biomarker expression in coho salmon. Environ. Sci. Pollut. R. 2018, 25, 7121-7128. [CrossRef]

10. Almeida, A.R.; Tacão, M.; Machado, A.L.; Golovko, O.; Zlabek, V.; Domingues, I.; Henriques, I. Long-term effects of oxytetracycline exposure in zebrafish: A multi-level perspective. Chemosphere 2019, 222, 333-344. [CrossRef] [PubMed]

11. Zhang, Q.; Ying, G.; Pan, C.; Liu, Y.; Zhao, J. Comprehensive evaluation of antibiotics emission and fate in the river basins of China: Source analysis, multimedia modeling, and linkage to bacterial resistance. Environ. Sci. Technol. 2015, 49, 6772-6782. [CrossRef] 
12. Yu, X.; Wu, Y.; Deng, M.; Liu, Y.; Wang, S.; He, X.; Allaire-Leung, M.; Wan, J.; Zou, Y.; Yang, C. Tetracycline antibiotics as PI3K inhibitors in the Nrf2-mediated regulation of antioxidative stress in zebrafish larvae. Chemosphere 2019, 226, 696-703. [CrossRef] [PubMed]

13. Lim, W.; Kim, D.; Jin, S.; Choi, Y.; Lee, S.; Huh, H.; Chae, S.; Lee, A. A case of fixed drug eruption due to doxycycline and erythromycin present in food. Allergy Asthma Immunol. Res. 2013, 5, 337-339. [CrossRef] [PubMed]

14. Johnson, A.C.; Keller, V.; Dumont, E.; Sumpter, J.P. Assessing the concentrations and risks of toxicity from the antibiotics ciprofloxacin, sulfamethoxazole, trimethoprim and erythromycin in European rivers. Sci. Total Environ. 2015, 511, 747-755. [CrossRef] [PubMed]

15. Gao, L.; Shi, Y.; Li, W.; Niu, H.; Liu, J.; Cai, Y. Occurrence of antibiotics in eight sewage treatment plants in Beijing, China. Chemosphere 2012, 86, 665-671. [CrossRef] [PubMed]

16. Rodrigues, S.; Antunes, S.C.; Correia, A.T.; Nunes, B. Acute and chronic effects of erythromycin exposure on oxidative stress and genotoxicity parameters of Oncorhynchus mykiss. Sci. Total Environ. 2016, 545, 591-600. [CrossRef] [PubMed]

17. Li, Z.; Liu, X.; Cheng, J.; He, Y.; Wang, X.; Wang, Z.; Qi, J.; Yu, H.; Zhang, Q. Transcriptome profiling provides gene resources for understanding gill immune responses in Japanese flounder (Paralichthys olivaceus) challenged with Edwardsiella tarda. Fish Shellfish. Immun. 2018, 72, 593-603. [CrossRef]

18. Ji, K.; Kim, S.; Han, S.; Seo, J.; Lee, S.; Park, Y.; Choi, K.; Kho, Y.; Kim, P.; Park, J. Risk assessment of chlortetracycline, oxytetracycline, sulfamethazine, sulfathiazole, and erythromycin in aquatic environment: Are the current environmental concentrations safe? Ecotoxicology 2012, 21, 2031-2050. [CrossRef]

19. Klüver, N.; König, M.; Ortmann, J.; Massei, R.; Paschke, A.; Kühne, R.; Scholz, S. Fish embryo toxicity test: Identification of compounds with weak toxicity and analysis of behavioral effects to improve prediction of acute toxicity for neurotoxic compounds. Environ. Sci. Technol. 2015, 49, 7002-7011. [CrossRef]

20. Reidy, S.P.; Kerr, S.R.; Nelson, J.A. Aerobic and anaerobic swimming performance of individual Atlantic cod. J. Exp. Biol. 2000, 203, 347-357.

21. Huey, R.B. Sprint velocity of tadpoles (Bufoboreas) through metamorphosis. Copeia 1980, 1980, 537-540. [CrossRef]

22. Driedzic, W.R.; Hochachka, P.W. Control of energy metabolism in fish white muscle. Am. J. Physiol. Content 1976, 230, 579-582. [CrossRef] [PubMed]

23. Kobayashi, N.; Yoshida, M.; Matsumoto, N.; Uematsu, K. Artificial control of swimming in goldfish by brain stimulation: Confirmation of the midbrain nuclei as the swimming center. Neurosci. Lett. 2009, 452, $42-46$. [CrossRef] [PubMed]

24. Baltz, D.M.; Chesney, E.J.; Tarr, M.A.; Kolok, A.S.; Bradley, M.J. Toxicity and sublethal effects of methanol on swimming performance of juvenile Florida pompano. Trans. Am. Fish. Soc. 2005, 134, 730-740. [CrossRef]

25. Hopkins, W.A.; Snodgrass, J.W.; Staub, B.P.; Jackson, B.P.; Congdon, J.D. Altered swimming performance of a benthic fish (Erimyzon sucetta) exposed to contaminated sediments. Arch. Environ. Contam. Toxicol. 2003, 44, 0383-0389.

26. Beamish, F. Swimming capacity. Fish Physiol. 1978, 7, 101-187.

27. Alsop, D.; Wood, C. The interactive effects of feeding and exercise on oxygen consumption, swimming performance and protein usage in juvenile rainbow trout (Oncorhynchus mykiss). J. Exp. Biol. 1997, 200, 2337-2346.

28. Mallatt, J. Fish gill structural changes induced by toxicants and other irritants: A statistical review. Can. J. Fish. Aquat. Sci. 1985, 42, 630-648. [CrossRef]

29. Wilson, R.W.; Bergman, H.L.; Wood, C.M. Metabolic costs and physiological consequences of acclimation to aluminum in juvenile rainbow trout (Oncorhynchus mykiss). 1: Acclimation specificity, resting physiology, feeding, and growth. Can. J. Fish. Aquat. Sci. 1994, 51, 527-535. [CrossRef]

30. Randall, D.; Brauner, C. Effects of environmental factors on exercise in fish. J. Exp. Biol. 1991, 160, 113-126.

31. Plaut, I. Critical swimming speed: Its ecological relevance. Comp. Biochem. Physiol. Part A: Mol. Integr. Physiol. 2001, 131, 41-50. [CrossRef]

32. Chen, Y.; Huang, Y.; Wen, C.; Wang, Y.; Chen, W.; Chen, L.; Tsay, H. Movement disorder and neuromuscular change in zebrafish embryos after exposure to caffeine. Neurotoxicol. Teratol. 2008, 30, 440-447. [CrossRef] [PubMed] 
33. Peng, W.; Lee, Y.; Chau, Y.; Lu, K.; Kung, H. Short-term exposure of zebrafish embryos to arecoline leads to retarded growth, motor impairment, and somite muscle fiber changes. Zebrafish 2015, 12, 58-70. [CrossRef] [PubMed]

34. Andrade, T.S.; Henriques, J.F.; Almeida, A.R.; Machado, A.L.; Koba, O.; Giang, P.T.; Soares, A.M.; Domingues, I. Carbendazim exposure induces developmental, biochemical and behavioural disturbance in zebrafish embryos. Aquat. Toxicol. 2016, 170, 390-399. [CrossRef] [PubMed]

35. Calder, W.A. Size, Function, and Life History; Courier Corporation: Chelmsford, MA, USA, 1996.

36. Somero, G.N.; Childress, J.J. Scaling of ATP-supplying enzymes, myofibrillar proteins and buffering capacity in fish muscle: Relationship to locomotory habit. J. Exp. Biol. 1990, 149, 319-333.

37. Milligan, C.L.; Wood, C.M. Intracellular and extracellular acid-base status and H+ exchange with the environment after exhaustive exercise in the rainbow trout. J. Exp. Biol. 1986, 123, 93-121. [PubMed]

38. Dobson, G.P.; Hochachka, P.W. Role of glycolysis in adenylate depletion and repletion during work and recovery in teleost white muscle. J. Exp. Biol. 1987, 129, 125-140.

39. Adachi, K.; Okuyama, T. Study on the reduced pyridine nucleotide dehydrogenase of bovine erythrocytes: I. Crystallization and properties of the reduced pyridine nucleotide dehydrogenase of bovine erythrocytes. Biochim. Biophys. Acta (BBA)-Enzymol. 1972, 268, 629-637. [CrossRef]

40. Gladwin, M.T.; Shiva, S. The Ligand Binding Battle at Cytochrome C Oxidase: How No Regulates Oxygen Gradients in Tissue; Am Heart Assoc: Dallas, TX, USA, 2009.

41. Nicholls, P.; Marshall, D.C.; Cooper, C.E.; Wilson, M.T. Sulfide Inhibition of and Metabolism by Cytochrome C Oxidase; Portland Press Ltd.: London, UK, 2013.

42. Amiard-Triquet, C. Behavioral disturbances: The missing link between sub-organismal and supra-organismal responses to stress? Prospects based on aquatic research. Hum. Ecol. Risk Assess. 2009, 15, 87-110. [CrossRef]

43. Granato, M.; Van Eeden, F.J.; Schach, U.; Trowe, T.; Brand, M.; Furutani-Seiki, M.; Haffter, P.; Hammerschmidt, M.; Heisenberg, C.; Jiang, Y. Genes controlling and mediating locomotion behavior of the zebrafish embryo and larva. Development 1996, 123, 399-413.

44. Nolan, P.M.; Peters, J.; Vizor, L.; Strivens, M.; Washbourne, R.; Hough, T.; Wells, C.; Glenister, P.; Thornton, C.; Martin, J. Implementation of a large-scale ENU mutagenesis program: Towards increasing the mouse mutant resource. Mamm. Genome 2000, 11, 500-506. [CrossRef]

45. Easter, S.S., Jr.; Nicola, G.N. The development of vision in the zebrafish (Danio rerio). Dev. Biol. 1996, 180, 646-663. [CrossRef] [PubMed]

46. Muto, A.; Orger, M.B.; Wehman, A.M.; Smear, M.C.; Kay, J.N.; Page-McCaw, P.S.; Gahtan, E.; Xiao, T.; Nevin, L.M.; Gosse, N.J. Forward genetic analysis of visual behavior in zebrafish. PLoS Genet. 2005, 1, e66. [CrossRef] [PubMed]

47. Oren, D.A. Bilirubin, REM sleep, and phototransduction of environmental time cues. A hypothesis. Chronobiol. Int. 1997, 14, 319-329. [CrossRef] [PubMed]

48. van de Pol, I.; Flik, G.; Gorissen, M. Comparative physiology of energy metabolism: Fishing for endocrine signals in the early vertebrate pool. Front. Endocrinol. 2017, 8, 36. [CrossRef]

49. Schwartz, M.W.; Woods, S.C.; Porte, D.; Seeley, R.J.; Baskin, D.G. Central nervous system control of food intake. Nature 2000, 404, 661-671. [CrossRef]

50. Anand, B.K.; Brobeck, J.R. Hypothalamic control of food intake in rats and cats. Yale J. Boil. Med. 1951, 24, 123.

51. Mayer, J. Regulation of energy intake and the body weight: The glucostatic theory and the lipostatic hypothesis. Ann. N. Y. Acad. Sci. 1955, 63, 15-43. [CrossRef]

52. Shimmura, T.; Nakayama, T.; Shinomiya, A.; Fukamachi, S.; Yasugi, M.; Watanabe, E.; Shimo, T.; Senga, T.; Nishimura, T.; Tanaka, M. Dynamic plasticity in phototransduction regulates seasonal changes in color perception. Nat. Commun. 2017, 8, 412. [CrossRef]

53. Zhang, J.; Liu, M.; Zhang, C.; Li, E.; Fan, M.; Huang, M. Transcriptomic analyses of tributyltin-induced sexual dimorphisms in rare minnow (Gobiocypris rarus) brains. Ecotox. Environ. Saf. 2018, 156, 18-24. [CrossRef]

54. Robinson, S.L.; Thiele, T.E. The Role of Neuropeptide Y (Npy) in Alcohol and Drug Abuse Disorders; Elsevier: Amsterdam, The Netherlands, 2017; Volume 136, pp. 177-197.

55. Decressac, M.; Barker, R.A. Neuropeptide Y and its role in CNS disease and repair. Exp. Neurol. 2012, 238, 265-272. [CrossRef] 
56. Heilig, M.; Widerlöv, E. Neurobiology and clinical aspects of neuropeptide Y. Crit. Rev. Neurobiol. 1995, 9, 115-136. [PubMed]

57. Tatemoto, K.; Neuropeptide, Y. Historyandoverview. In Michel, MC Handbook of Experimental Pharmacology; Springer: Berlin/Heidelberg, Germany, 2004.

58. Colmers, W.F.; Bahh, B.E. Neuropeptide Y and epilepsy. Epilepsy Curr. 2003, 3, 53-58. [CrossRef] [PubMed]

59. Acuna-Goycolea, C.; Tamamaki, N.; Yanagawa, Y.; Obata, K.; van den Pol, A.N. Mechanisms of neuropeptide Y, peptide $Y Y$, and pancreatic polypeptide inhibition of identified green fluorescent protein-expressing GABA neurons in the hypothalamic neuroendocrine arcuate nucleus. J. Neurosci. 2005, 25, 7406-7419. [CrossRef] [PubMed]

60. Reichmann, F.; Holzer, P. Neuropeptide Y: A stressful review. Neuropeptides 2016, 55, 99-109. [CrossRef] [PubMed]

61. Yehuda, R.; Brand, S.; Yang, R. Plasma neuropeptide Y concentrations in combat exposed veterans: Relationship to trauma exposure, recovery from PTSD, and coping. Biol. Psychiat. 2006, 59, 660-663. [CrossRef]

62. Heinzmann, C.; Ladias, J.; Antonarakis, S.; Kirchgessner, T.; Schotz, M.; Lusis, A.J. RFLP for the human lipoprotein lipase (LPL) gene: HindIII. Nucleic Acids Res. 1987, 15, 6763. [CrossRef]

(C) 2020 by the authors. Licensee MDPI, Basel, Switzerland. This article is an open access article distributed under the terms and conditions of the Creative Commons Attribution (CC BY) license (http://creativecommons.org/licenses/by/4.0/). 